\title{
Potential Management Development Of Batik Small-Medium Enterprise In Pilang Village, Sragen
}

\author{
Asri Laksmi Riani', Edi Kurniadi², Mohammad Cholil ${ }^{3}$, Mohammad Amien Gunadi ${ }^{4}$, \\ Atmaji $^{5}$, Agung Prabowo ${ }^{6}$ \\ 1,2,3,4,5 Department of Management, Faculty of Economic and Business, \\ Sebelas Maret University, Surakarta, Indonesia \\ ${ }^{6}$ Magister Management Graduate programe, Faculty of Economic and Business, \\ Sebelas Maret University, Surakarta, Indonesia \\ Asrilaksmi_fe@staff.uns.ac.id
}

The study was conducted in Batik Small-Medium Enterprise (Batik SMEs) in Pilang Village of Sragen Regency. Pilang village is one of the producers of Batik, it considerably contributes to the Batik market in Solo region. The study was aimed at finding out the condition and the potential of development through management comprising financial, human resource, marketing, and production management. The Descriptive quantitative method was employed, the respondents were ten SMEs Batik entrepreneurs. The study found that SMEs relied on traditional and limited financial management methods. It was also found that their marketing aspect had not adopted a modern marketing and promotion strategy. Their production has run well, however they face hindrances in product innovation and design with local characteristics. Then, human resource management also faced obstacles in on time delivery, creativity, and payment system.

Keywords: management, batik, small and medium enterprise / sme, qualitative descriptive study

Penelitian dilakukan pada sentra Usaha Kecil Menegah (UKM) Batik di desa Pilang Kabupaten Sragen. Desa Pilang merupakan salah satu sentra penghasil kain batik dan berkontribusi besar pada pasar batik di kawasan Solo Raya. Penelitian ini bertujuan untuk mengetahui kondisi dan potensi pengembangan yang dapat dilakukan melalui pendekatan tata kelola manajemen yang terdiri atas manajemen keuangan, manajemen sumber daya manusia, manajemen pemasaran, dan manajemen produksi.Metode penelitian kuantitatif deskriptif digunakan dengan responden pengusaha UKM Batik sebanyak 10 responden. Temuan penelitian ini menunjukkan bahwa aspek pengelolaan keuangan dari UKM mengandalkan metode-metode pengelolaan tradisional yang masih terbatas. Dari aspek pemasaran juga belum mengadopsi strategi pemasaran dan promosi yang luas, aspek produksi saat ini telah berjalan dengan baik namun masih menemukan kendala dalam inovasi produk dan desain khas daerah. Selanjutnya dari aspek SDM masih menemui kendala dalam pengelolaan pembukuan keuangan dan sistem pembayaran.

Kata kunci: management, batik,usaha kecil menengah, penelitian kualitatif deskriptif 


\section{INTRODUCTION}

Small-Medium Enterprise (SME) becomes one of the biggest contributors of Indonesian economy. The contribution of this sector to gross domestic product increases from 57.84 percent to 60.34 percent in the last five years (Data from Ministry of Industry, 2019). Batik SMEs contribution is expected to keep increasing, and this gains attentions from various parties and becomes priority in local and national levels. Potential development of SME from various regions possesses unique characteristics. Small-Medium Enterprise for Batik (Batik SMEs) in Sragen regency is one of the biggest Batik product contributors in Solo. There were 4.702 hand-drawn batik (batik tulis) companies/industries in Sragen Regency. Batik industry in Sragen produced 4,287,405 scores of batik fabric (BAPPEDA Kabupaten Sragen, 2012), this industry becomes one of the wheels of local economy. Historically, Batik Industry in Sragen began to show its contribution since 2000s. Majority of today's Sragen Batik craftsmen were batik craftsmen in Laweyan, Solo. Nonetheless, the advancement of technology and the easiness of loans for finance make them able to establish their own independent business.

Pilang village is one of the centers of Batik Sragen possessing excellence in hand-drawn batik. In general, SMEs in Pilang village is categorized as small-scale business, their monthly average production is $300-500$ pieces of batik. They use Standardized conventional tools to maintain their excellent quality. The majority of the actors of Batik SMEs in this village were batik craftsmen in batik center in Laweyan, Solo. This makes their product share similarity either in quality or design with those made in Laweyan. Competitiveness becomes a pivotal issue faced by SMEs in Indonesia in general (Dewanti et al, 2013). This issue also is also faced by Batik SMEs in Pilang village, they face a number of obstacles such as stagnant demands, and the increase of production material cost. To face challenging business competition, an SMEs requires managerial capacity improvement. Prior study by Morrison et al (2003) also stated that constrained managerial competencies became an inhibiting factors of business growth. Many SMEs entrepreneurs perceive themselves to have limited managerial ability, primarily because their prior interests and educational background.

The present study aims to depict the condition and characteristics of Batik SMEs in Pilang Village through qualitative descriptive study. This approach is used to discover the latest conditions regarding the management and competitiveness of Batik SMEs. The result of the study can be used as feedback for the development of Batik SMEs in the future.

\section{RESEARCH METHOD}

The present study employed qualitative descriptive ap- proach. Descriptive approach is a research method aiming at studying the condition of an object by identifying the characteristic of a phenomenon/object based on field observation/exploration (Williams, 2007). The subjects of the study were ten entrepreneurs of Batik SMEs in Pilang Village. They are Batik Putri Nderbolo, Batik Morinda, Batik Jito, Batik Ontoredjo, Batik Nurul Hidayah, Batik Sri Padmi, Batik Jantran, Griya Batik AV, Batik Pilang, dan Batik Revansya. The data were collected using interviews and discussions with the subjects of the study. The observation was also conducted on all aspects of management comprising financial, production, and human resource aspects.

Literature study on government data of SMEs use to determine the current conditions of SMEs in the region. Several previous study also mentioned to comparation between our findings and prior study and findings in other places and condition.

\section{RESULT AND DISCUSSION}

Financial Aspect

The health of a company, both large businesses and small businesses or even SMEs can be known by looking at the financial statements they have. High sales cannot ensure that profits are also high. This is caused by the profit obtained after reducing the amount of revenue with the amount of any cost and capital. Therefore, businesses need financial records so that the amount of business profits can be seen more clearly and can know the profit or loss. Financial statements can be prepared when the business conducts all financial records as reports of transactions that occur in its business. Many SME business people often forget the financial records of the business they are running. The financial statements serve as a reference for implementing the strategy. Without financial reports, businesses will have difficulty in determining a strategy that is in accordance with the conditions in the form of challenges and business obstacles.

Financial aspects become one of the important aspects in strategy. This research tries to observe several financial aspects that occur in Batik SMEs. Among them are the issues of bookkeeping, financial records, product price planning, and the basis of price determination. From table 1 above, it is found that $50 \%$ of Batik SMEs never performs bookkeeping, $40 \%$ of them sometimes performs bookkeeping, while only $10 \%$ of them always perform bookkeeping.Our findings show that there is no professional and consistency of bookkeeping process. The issue of low discipline in recording itself occurs in almost all SMEs in Indonesia. Batik SMEs in Pilang Village are only recorded when there are large orders and have not been collected or well documented. 
Table 1. Financial Aspect

\begin{tabular}{|c|c|c|c|}
\hline No & Description & Total & Percentage \\
\hline A & Bookkeeping & & \\
\hline 1 & $\begin{array}{l}\text { Always perform Bookkeep- } \\
\text { ing }\end{array}$ & 1 & 10 \\
\hline 2 & Sometimes & 4 & 40 \\
\hline 3 & Never & 5 & 50 \\
\hline $\mathrm{B}$ & Financial Recording & & \\
\hline 1 & $\begin{array}{l}\text { Always perform financial re- } \\
\text { cording }\end{array}$ & 1 & 10 \\
\hline 2 & Sometimes & 4 & 40 \\
\hline 3 & Never & 5 & 50 \\
\hline $\mathrm{C}$ & Pricing Plan & & \\
\hline 1 & Make by themselves & 2 & 20 \\
\hline 2 & Adopt from others & 8 & 80 \\
\hline $\mathrm{D}$ & Basis for Pricing & & \\
\hline 1 & Profit-oriented or targeted & 4 & 40 \\
\hline 2 & Adding transportation cost & 6 & 60 \\
\hline 3 & $\begin{array}{l}\text { Special price for loyal cus- } \\
\text { tomer }\end{array}$ & 5 & 50 \\
\hline
\end{tabular}

Source: Primary Data (2019)

Similar condition to that of bookkeeping. The financial recording should have been done when they perform bookkeeping. The recording of business finances is also not yet a concern for SMEs. The reasons why SMEs are reluctant to do good financial records is because it is quite troublesome and there are no concise and simple guidelines that can be used as a reference. From table 1, it is found that in making pricing plan, $20 \%$ of them made it by themselves, while $80 \%$ of the adopt from other SMEs. In general there are not many differences in production costs between SMEs. So the price level they offer follows the market price.The data shows three factors in determining the selling price of the products they produce. $60 \%$ of SMEs determined their price based on transportation cost, $50 \%$ of them did it based on special price for loyal customers, while $40 \%$ them did it based on profit orientation or target.
The majority of SMEs still employed traditional methods in managing their finance. Eventhough, prior research has shown that the lack of financial management skills and application of financial management practices became of the biggest factors contributing to SME failure. Ligthelm (2010) found that business and financial management skills can be classified as the strongest predictors of small business survival.Batik SMEs in this study had not possessed a proper and discipline bookkeeping. This makes them difficult to find the real financial position and condition from the business. Regarding pricing plan, we found that the price tends to follow the market price. Eventhough, having a sustainable pricing policy was very important to business. Beside that, small industries need to be very careful about pricing decision in highly competitive environment (Sheetal et al. 2012). Meanwhile, the bases for pricing are the expected profit, transportation cost, and special price for loyal customer. Entrepreneurs in SME tend to focus on value for money fortheir customers and may try to balance price with other aspects such as the quality of the product (Gilmore, 2011). In general, the management of financial aspect is still traditional, however, these methods were used due to their simplicity, there has not been a priority to have better management.

\section{Marketing Aspect}

Marketing is an effort aimed at planning, determining the price of goods or services, promoting it, and distributing it to consumers so that it can satisfy consumers. Small company like start-ups and SMEs have little spend on promotion. Batik SME marketing strategy also based on networking and mouth to mouth. Marketing by networking is both a natural and an acquired competence (Carson et al, 2004). Gilmore (2007) also stated that entrepreneurs can use networks to help business improve their competence in decision making and delivering some marketing activity Understanding entrepreneurial marketing is based on knowing how SMEs owner or entrepreneurs actually do business and how they make decisions, deliver their market offering in market within some constraints like limited resources, expertise, impact, and size (Gilmore at al. 2007).

Therefore, they need to promote their business by word of mouth and other below the line activity. The marketing aspect becomes an issue that is further investigated. One of the problems faced is the stagnation in the number of demand which is one indication of the cause is the limitations of marketing strategies currently applied. Table 2 show that all respondents sell their product in their business site $(100 \%)$. Their marketing strategy still relied on direct promotion to customer, so there was a limited marketing coverage. Only $10 \%$ or one business used online marketing. 
Table 2. Marketing Problems

\begin{tabular}{|c|c|c|c|}
\hline No & Description & Total & Percentage \\
\hline A & Marketing Method & & \\
\hline 1 & Promotion in Business site & 10 & 100 \\
\hline 2 & $\begin{array}{l}\text { Promotion straight to the } \\
\text { Customer }\end{array}$ & 8 & 80 \\
\hline 3 & Marketed to other cities & 4 & 40 \\
\hline 4 & Online marketing & 1 & 10 \\
\hline $\mathrm{B}$ & Marketing Problems & & \\
\hline 1 & $\begin{array}{l}\text { Need for new product pat- } \\
\text { tern }\end{array}$ & 3 & 30 \\
\hline 2 & Need for online marketing & 10 & 100 \\
\hline 3 & $\begin{array}{l}\text { Want to learn online mar- } \\
\text { keting }\end{array}$ & 10 & 100 \\
\hline 4 & $\begin{array}{l}\text { Need for increasing cus- } \\
\text { tomer }\end{array}$ & 9 & 90 \\
\hline 5 & Limited Creativity & 5 & 50 \\
\hline
\end{tabular}

Source: Primary Data (2019)

Research found that Batik SMEs faced several marketing problems. First, they need to tried online marketing, and they wanted to learn about that, next they also had a difficulties to obtain more customers, limited creativity, and need for new unique pattern in product.From the marketing aspect, in general, they still used conventional marketing methods with limited marketing channels and promotions. They still relied on the local market. They had not taken advantage of online media. Their marketing process still relied on distribution channels to wholesalers. the entrepreneur will often use his peersand business contacts to sound product and gather information. The increase in demand is also limited since Batik SMEs has not had a specific strategy and budget for marketing, promotion, and advertisement.

The limited marketing strategy run by SMEs is one of the challenges that must be solved. Maximizing the multichanel strategy of using a variety of marketing channels can be used to increase sales to product branding (Kumar $\&$ Venkatesan, 2005). So in the future SMEs need more effort to find alternative marketing strategies. All of Batik SMEs in this study agree that they need to use online marketing, they wanted to learn to use that media. This intention also mentioned by Slamet et al. (2016) that SME In Indonesia realize the power of the internet and digital devices in improving business performance. This medium provide an huge potential and relatively inexpensive cost. This is in line with the need to gain more customers and limitedness in the aspect of creativity.

\section{Production Aspect}

As an industry, production and innovationbecame a main factor determines the success of a business (Love and Roper, 2015).Batik SMEs is one of the creative industries that is based on the creativity of craftsmen. In this aspect we gather information in terms of creative product creation, motivation to create and develop regionally-specific designs, and the methods of making them. Pilang village's batik has a distinctive design pattern that has the potential to become a mainstay product. However, this unique design pattern has not been explored well because it is less popular in the national batik market. in this study we also observed about SME perseption about motivation to make this unique design pattern.

Table 3. Production Aspect

\begin{tabular}{|c|c|c|c|}
\hline No & Description & Total & Percentage \\
\hline A & $\begin{array}{l}\text { Creative Product Craft- } \\
\text { ing }\end{array}$ & & \\
\hline 1 & Imitating & 10 & 100 \\
\hline 2 & Based on order & 5 & 50 \\
\hline 3 & Modification & 8 & 80 \\
\hline 4 & Others & 5 & 50 \\
\hline B & $\begin{array}{l}\text { Motivation to Make Lo- } \\
\text { cal unique design }\end{array}$ & & \\
\hline 1 & $\begin{array}{l}\text { To be different from } \\
\text { others }\end{array}$ & 4 & 40 \\
\hline 2 & $\begin{array}{l}\text { To gain the essence of } \\
\text { design }\end{array}$ & 2 & 20 \\
\hline 3 & To be easily recognized & 5 & 50 \\
\hline $\mathrm{C}$ & $\begin{array}{l}\text { Methods of Making Lo- } \\
\text { cal Unique Design }\end{array}$ & & \\
\hline 1 & Trying new design & 2 & 20 \\
\hline 2 & $\begin{array}{l}\text { Seeing unique local de- } \\
\text { sign }\end{array}$ & 3 & 30 \\
\hline 3 & $\begin{array}{l}\text { There are some local } \\
\text { uniqueness }\end{array}$ & 3 & 30 \\
\hline
\end{tabular}




\begin{tabular}{llll}
\hline 4 & Do not know & 5 & 50 \\
\hline 5 & Imitating the existing & 6 & 60 \\
\hline
\end{tabular}

Source: Primary Data (2019)

Table 3 shows that in production aspect, all of the SME make product used replication method, the other methods were modification, based on order pattern and model, and others methode. Sometimes new model developed based on customer request and design.In this data, we can conclude that SME Batik have low motivation to make local unique design. But several have intention to do that. Regarding the motivation to make unique local product, the motivation was to be easily recognized $(50 \%)$, to be different (40\%), to find the essence of design (20\%) Table 3 also shows that the methods they use to create a unique local product are by imitating the existing design (100\%), while $50 \%$ stated that they did not know the method, $30 \%$ of them did it by seeing unique local design, and the other 30\% stated that there are some local uniqueness. Only $20 \%$ of them tried new designs.

From the production aspect, SME Batik in Pilang Village did not face any significant technical problems. Their production performs with optimal output. However, the data shows that the creation of their creative Entrepreneurs are usually focused on trying to be innovative, especially in relation to offering something into the market and make some differentiation in their company products (Gilmore, 2011). Product still relies on the replication method, although most of them made some modifications. They wanted to craft a local design so that their products can be easily recognized and different from other batik designs. The current production capacity had not been optimum, the production can be increased but it cannot be done due to stagnant in demand. In other words, the problems do not stem from production aspect. Besides, in creating design, they still rely on replication, they took minimum effort to do research or trying to make new designs. Creating new design requires more resources, it also finds risk of rejection in the market. Finally making of new products by referring to unique local design was still minimum. Eventhough, developing new product its important to small business growth (Morrison et al. 2003). Another study by Yan and Chew (2011) conduct in Chinesse SMEs stated that differentiation and innovation of product was positively related to construction SMEs' performance.

\section{Human Resource Aspect}

Human resource management is the process of planning, organizing, directing, controlling, and supplying human resources to support a business. There is evidence that effective people management can play a significant part in ensuring the success of innovation and so contributing positively to SME success (Laursen and Salter, 2006). Human Resource Management at SME Batik in Pilang village is still very traditional based on non formal domestic industry. In this study we observed about on time delivery, human resources problem, and employee motivation.

Table 4. Human Resource Aspect

\begin{tabular}{|c|c|c|c|}
\hline No & Description & Total & Percentage \\
\hline A & $\begin{array}{l}\text { The Accuracy of Accom- } \\
\text { plishment and Delivery }\end{array}$ & & \\
\hline 1 & Late Often & 5 & 50 \\
\hline 2 & Sometimes & 7 & 70 \\
\hline 3 & Almost, always on time & 3 & 30 \\
\hline $\mathrm{B}$ & Actual Problems & & \\
\hline 1 & Finding unique design & 6 & 60 \\
\hline 2 & $\begin{array}{l}\text { Cashless payment sys- } \\
\text { tem }\end{array}$ & 3 & 30 \\
\hline 3 & $\begin{array}{l}\text { No standardized book- } \\
\text { keeping }\end{array}$ & 7 & 70 \\
\hline 4 & $\begin{array}{l}\text { Difficulty in obtaining } \\
\text { material }\end{array}$ & 3 & 30 \\
\hline $\mathrm{C}$ & $\begin{array}{l}\text { Entrepreneur's Motiva- } \\
\text { tion }\end{array}$ & & \\
\hline 1 & $\begin{array}{l}\text { Wanted to advance the } \\
\text { business/ get more order }\end{array}$ & 10 & 100 \\
\hline 2 & $\begin{array}{l}\text { Acquiring new custom- } \\
\text { ers }\end{array}$ & 5 & 50 \\
\hline 3 & $\begin{array}{l}\text { Creating many design } \\
\text { pattern }\end{array}$ & 3 & 30 \\
\hline 4 & $\begin{array}{l}\text { Performing online mar- } \\
\text { keting }\end{array}$ & 8 & 80 \\
\hline 5 & $\begin{array}{l}\text { Having different or } \\
\text { unique pattern }\end{array}$ & 8 & 80 \\
\hline
\end{tabular}

Source: Primary Data (2019)

From human resource aspect, table 4 shows that $70 \%$ of them were sometimes on time, often late $(30 \%)$, while only $30 \%$ of them were always make on time. From these figures it can be seen that SMEs are still having difficulties in meeting demand on time. Production planning has not been designed in detail and discipline so that delays are prone to occur. Our findings also found that the problems regarding human resources were seven Batik SME didnt have a special bookkeeping and only three of them can 
accomodate Cashless payment system. Next issue is about creativity, six Batik SMEs can finding unique design but still in limited production. We also found that all of the entrepreneur's motivations were to advance their business/ gain more demand, eight SMEs want to perform online marketing and to have different or unique pattern, but only half of them want to Acquiring new customers.

Issues on Human resources were low focus on creativity, resulting in low innovation and new design or product. Another issue is related to production time accuracy, which had not been optimally managed. Its very imprortant to SME to focusing in human resources improvement. Morrison et al. (2003) found that the human factor constitutes the overwhelming force that determines whether or not a business will survive and prosper.This issue also mentioned by Gilmore. (2011) that SME in particular delivery problems can arise where operational plans are over-optimistic or where there is poor production control. Next, the competence in bookkeeping and payment system can also be improved. Furthermore, the study found that all SME wanted to gain more demand, yet this had not been accommodated by encouragement to create product with new designs. From the observation, it was also found that they were highly motivated to adopt online marketing and create different designs and products.

\section{CONCLUSION AND RECOMMENDATION}

The increasing of demand and appreciation toward local culture from domestic and international market is an important moment to optimalize all potention of batic product. improvement of managerial skills of SMEs in all managerial aspects became a challenge dan need attention from various parties such as government, academician, and privat sector. SMEs entrepreneur often directly involved in the day to day running of the business and may get caughtup in operational activities, they may have less time to plan and doing managerial function more strategically. Prior study in different region and condition also stated about important of managerial competencies in business growth (Morrison et al. 2003; Ligthelm, 2010; Gilmore, 2011).

Batik SME's in Pilang Village holds huge potential for development. However, they faced several difficult due to various obstacles and limitedness. The obstacles and challenges they faced are similar to those faced by the majority of SME in Indonesia. In financial aspect, these SMEs didnt have a proper bookkeeping. Our findings show that SMEs need to give more attention on financial aspects of their business. Previous study stated that financial aspect became an important factors in business growth (Ligthelm, 2010). Marketing network became an important issue in develop business (Rocks, 2005). Effective marketing strategic could help SMEs to gain competitive advantage via superior performance (Yan and Chew, 2011). In the marketing aspect, they still relied on the conventional methods, only one SME was used online marketing.But other entrepreneur have intention to adopt new marketing methode like online based marketing. There was no significant obstacle in production aspect, however they were limited by design innovation and new product. Human resource aspect also did not face serious problems regarding motivation, however they still had opportunity to improve their competence in bookkeeping, design innovation, and payment system.

\section{REFERENCES}

Aha. (2019). Kontribusi UMKM Naik. https://kemenperin.go.id/artikel/14200/Kontribusi-UMKM-Naik. Diakses pada 1 Oktobe 2019 pukul 22.10.

Ananda., A, and Susilowati, D. (2017). Pengembangan Usaha Mikro Kecil Dan Menengah (Umkm) Berbasis Industri Kreatif Di Kota Malang. Jurnal Ilmu Ekonomi. Vol X Jilid X. pp. 120-142.

Carson, D., Gilmore, A. and Rocks, S. (2004). SME marketing networking: a strategic approach. Journal of Strategic Change, Vol. 13 No. 7, pp. 369-82.

BAPPEDA Kabupaten Sragen, 2012

Dewanti, R., Melati, I., and Simbolon, F. (2013). Pengembangan Model Daya Saing Umkm Batik Melalui ECS. BINUS BUSINESS REVIEW Vol. 4 No. 1.pp. 41-57.

Gilmore., A. (2011). Entrepreneurial and SME marketing. Journal of Research in Marketing and Entrepreneurship. Vol. 13 No. 2, pp. 137-145.

Gilmore, A., Gallagher, D. and Henry, S. (2007). E-marketing and SMEs: operational lessons for the future. European Business Review, Vol. 19 No. 3, pp. 234-47.

Kumar, V., \& Venkatesan, R. (2005). Who are the multichannel shoppers and how do they perform?: Correlates of multichannel shopping behavior. Journal of Interactive Marketing, 19(2), 44-62.

Laursen., K and Salter A. (2006). Open for innovation: The role of openness in explaining innovation performance among UK manufacturing firms. Strategic Management Journal 27, pp. 131-150.

Ligthelm, A. (2010). Entrepreneurship and small business sustainability. Southern African Business Review, 14(3), pp.131-153.

Love, J. H., and Roper, S. (2015). SME innovation, exporting and growth: A review of existing evidence. International Small Business Journal, 33(1), pp. 28-48. 
Morrison, A., Breen, J. and Shameen, A. (2003). Small business growth: Intention, ability and opportunity. Journal of Small Business Management, 41(4).

Rocks, S., Gilmore, A. and Carson, D. (2005). Developing strategic marketing through the use ofmarketing networks. Journal of Strategic Marketing, Vol. 13, June, pp. 81-92.

Satria., D dan Preswari. (2011). strategi pengembangan industri kreatif untuk meningkatkan daya saing pelaku ekonomi lokal. jurnal aplikasi managemen, 9, halaman. 301-308.

Sheetal, S., and Kumar, R.(2012). Marketing Strategies of Small and Medium Enterprises: A Sample Survey. International Journal of Management Sciences, Vol. 01, Issue 02, pp. 60-71.

Slamet., R, Nainggolan, B, Roessobiyatno, Ramdani, Heru, and Hendriyanto, Agung. (2016). Development Strategy of Digital Start Up To Confront the Era of Free Market. Jurnal Manajemen Indonesia. Vol.16 - No.2

Williams, C. (2007). Research Methods . Journal of Business and Economic Research, page. 65-72

Yan, S. and Chew, D. A. S. (2011). An investigation of marketing strategy, business environment and performance of construction SMEs in China. African Journal of Business Management, Vol. 5(6), pp. 2396-2405. 